\title{
Beware Biofilm! Dry biofilms containing bacterial pathogens on multiple healthcare surfaces; a multicentre study
}

K. Ledwoch ${ }^{a}$, S. J. Dancer ${ }^{b, c}$, J. A. Otter ${ }^{d}$, K. Kerr ${ }^{a}$, D. Roposte ${ }^{a}$, L. Rushton ${ }^{e}$, R. Weiser ${ }^{e}$, E. Mahenthiralingam ${ }^{\mathrm{e}}$, D. Muir, J.-Y. Maillard ${ }^{\mathrm{a}^{*}}$

aSchool of Pharmacy and Pharmaceutical Sciences, Cardiff University, Cardiff, UK

${ }^{\mathrm{b}} \mathrm{NHS}$ Lanarkshire, Scotland, UK

'School of Applied Sciences, Edinburgh Napier University, Scotland, UK

${ }^{d}$ NIHR Health Protection Research Unit (HPRU) in HCAls and AMR at Imperial College London, and Imperial College Healthcare NHS Trust, Infection Prevention and Control, London, UK.

eSchool of Biosciences, Cardiff University, Cardiff, UK

fSchool of Earth and Ocean Sciences, Cardiff University, UK

${ }^{*}$ Corresponding author:

Prof Jean-Yves Maillard: School of Pharmacy and Pharmaceutical Sciences, Cardiff University Redwood Building, King Edward VII avenue, Cardiff CF10 3NB, UK telephone: $+44(0) 2920879088$

e-mail: maillardj@cardiff.ac.uk

Keywords: Biofilms, Environmental microbiology, Healthcare, Pathogens, Healthcareassociated infections (HCAls)

Short title: Dry biofilms in healthcare settings

\section{Word count:}

Text: $3385 / 4000$

Figures: (4)

Tables: (1) 


\section{SUMMARY}

Background: Wet biofilms associated with medical devices have been widely studied and their link with healthcare associated infections (HCAls) is well recognised. Little attention has been paid to the presence of dry biofilms on environmental surfaces in healthcare settings.

Aim: To investigate the occurrence, prevalence, and diversity of dry biofilms on hospital surfaces.

Method: 61 terminally cleaned items were received from three different UK hospitals. The presence of dry biofilm was investigated using culture-based methods and scanning electron microscopy (SEM). Bacterial diversity within biofilms was investigated using RISA-PCR and next generation sequencing.

Findings: Multi-species dry biofilms were recovered from $95 \%$ of 61 samples. Abundance and complexity of dry biofilms were confirmed by SEM. All biofilms harboured Gram-positive bacteria including pathogens associated with HCAls; $58 \%$ of samples grew methicillinresistant Staphylococcus aureus (MRSA). Dry biofilms had similar physical composition regardless of the type of items sampled or the ward from which the samples originated. There were differences observed in the dominance of particular species: dry biofilms from two hospitals contained mostly staphylococcal DNA, whereas more Bacillus spp. DNA was found on surfaces from the third hospital.

Conclusion: The presence of dry biofilms harbouring bacterial pathogens is virtually universal on commonly used items in healthcare settings. The role of dry biofilms in spreading HCAls may be underestimated. The risk may be further exacerbated by inefficient cleaning and disinfection practices for hospital surfaces. 


\section{Introduction}

Healthcare associated infections (HCAls) affect approximately $20 \%$ of patients in the National Health Service (NHS), causing significant mortality and financial losses with yearly cost for the healthcare systems estimated to be at least $\$ 1$ billion $[1,2]$.

A sizable proportion of HCAls are preventable through improved practices such as environmental hygiene, hand hygiene, use of personal protective equipment, and screening and isolation; some estimate this preventable portion to be $20-30 \%[3,4]$. Cleaning is used to reduce microbial burden on surfaces, but methods vary widely between hospitals. Most UK hospitals use detergents for routine cleaning. Chlorine-based disinfectants are usually reserved for terminal or specialised cleaning of areas exposed to antibiotic-resistant bacteria and Clostridium difficile, or during high-risk incidents or outbreaks. Efficacy of the cleaning process is dependent upon type of equipment, consumables, microbiocidal activity, allotted time and motivation of cleaning and/or nursing staff $[5,6]$. There is evidence that enhanced cleaning is cost-effective [7].

Although $98 \%$ of patients felt that their hospital room or ward was cleaned properly, visual audits used in monitoring the cleanliness of institutions are insufficient $[8,9]$. The best evidence for the role of the environment comes from studies showing the risk of infection for patients admitted into a cleaned room recently vacated by a patient with the same pathogen [10. Microbial pathogens can persist on surfaces for days, months and even years unless removed by some cleaning or disinfection process [11]. Bacterial biofilms are commonly identified on some medical devices and are associated with the presence of moisture or/and liquid, for example biofilms on medical devices such as urinary catheters, tracheal tubes, breast implants, endoscopes. Around 65\% cases of HCAls are associated with "wet" biofilms [12]. However, more recently, biofilm has been discovered on dry surfaces, despite effective infection control measures. These biofilms are referred to as "dry" biofilms $[13,14]$. 
To date, evidence of the presence of dry biofilms on surfaces in healthcare settings remain limited. This study aims to provide a better appreciation of the scale, extent, and composition of dry biofilms on surfaces that are regularly touched by healthcare workers.

\section{MATERIALS AND METHODS}

\section{Samples}

Samples were collected from different wards and departments from three different hospitals in Wales (Hospital A), Scotland (Hospital B) and England (Hospital C), including Trauma \& Orthopaedics, Adult Intensive Care, Joint Assessment Unit, Acute admission unit, Kidney and transplant, Nephrology, Cardiology, Gastroenterology, Intensive therapy unit and Haematology (Table I). Items collected included hand sanitising bottles, keyboards, patient folders and clipboards. In addition, one hospital provided a commode, a chair and wooden tray (part of a food trolley). Due to usage of electronic notes, hospital C was unable to provide any patient folders. All samples were kept in sterile bags to avoid cross-contamination during transportation. Sample processing was carried out under aseptic conditions.

\section{Selection of sampling area}

A key was removed from each keyboard and tested separately. The keys selection was made based on English letter frequency. Letters with similar frequencies were tested $(E, T, A$ and O). Folders, clipboards, the chair, commode, sanitising bottles and the trolley were sampled from the "high touch" areas. In order to ensure the same surface area was investigated for the different materials a $1.5 \times 1.5 \mathrm{~cm}$ squares were cut from each sample.

\section{Sample rinse and "sterility" testing}

Samples were placed in $50 \mathrm{~mL}$ polypropylene conical Falcon ${ }^{\mathrm{TM}}$ tubes (Fisher Scientific, Loughborough, UK) containing $30 \mathrm{~mL}$ of sterilised water and mixed with a Fisherbrand $®$ vortex shaker (Fisher Scientific, Loughborough, UK) for 1 minute. After three consecutive rinsing steps, a sterile cotton swab (ThermoFisher Scientific, Newport, UK) was streaked over the 
surface of the sample and incubated at $37^{\circ} \mathrm{C}$ overnight onto PP0280 TSA plate (EO Labs, Bonnybridge, UK). A sample was presumed free from planktonic bacteria if there was no bacterial growth observed after rinsing.

\section{Determination of the presence of sessile bacteria}

Following rinsing step, samples were placed into $50 \mathrm{~mL}$ polypropylene conical tube containing $30 \mathrm{~mL}$ of tryptone soya broth (TSB; Oxoid Ltd., Basingstoke, UK) and incubated in Sanyo orbital incubator (ThermoFisher Scientific, Newport, UK) at $37^{\circ} \mathrm{C}$ at $180 \mathrm{RPM}$. The broth was examined for sign of turbidity every 24 hours.

Microbial species determination by genotypic analysis (RISA)

Ribosomal RNA (rRNA) intergenic spacer analysis (RISA) is a method of microbial community analysis to compare samples without culture-dependent bias. Samples were prepared as follows: turbid broths were incubated overnight and centrifuged at $1,400 \mathrm{~g}$ for $10 \mathrm{~min}$ at $20^{\circ} \mathrm{C}$. The supernatant was discarded, and the pellet was re-suspended with $500 \mu \mathrm{L}$ of TSB. Five hundred $\mu \mathrm{L}$ of $4 \mathrm{M}$ guanidine isothiocyanate (UltraPure ${ }^{\mathrm{TM}}$, ThermoFisher Scientific, Newport, UK) was added and the suspension was mixed with Wizard ${ }^{\mathrm{TM}}$ infrared vortex mixer (Firsherbrand ${ }^{\mathrm{TM}}$, Fisher Scientific, Loughborough, UK) at 2,000 rpm. One $\mathrm{mL}$ of culture mix was added into the tubes containing $1 \mathrm{~g}$ of $0.1 \mathrm{~mm}$ diameter zirconia/silica beads (Thistle Scientific, Glasgow, UK) and suspensions were mixed in Bead Bug homogeniser (Benchmark Scientific, Cole-Parmer ${ }^{\circledR}$, St Neots, UK) at 2,800 shaking speed for 2 min. DNA was amplified with Maxwell囚 16 Instrument (Promega, Southampton, UK) and quantified by Quibit ${ }^{\circledR} 3.0$ fluorometer (ThermoFisher Scientific, Newport, UK). The internal transcribed spacer (ITS) bacterial region between the $16 \mathrm{~S}$ rRNA and $23 \mathrm{~S}$ rRNA subunit genes was amplified with 1406F (TGYACACACCGCCCGT, Eurofins Genomics, Ebersberg, Germany) and 23SR (GGGTTBCCCCATTCRG, Eurofins Genomics, Ebersberg, Germany) primers by running RISA-PCR in thermal cycler (BIO-RAD, Watford, UK) [15]. 
Microfluidic separation was performed with a 2100 Bioanalyser Instrument (Agilent Technologies Ltd, Craven Arms, UK) using DNA 7500 chip (Agilent Technologies Ltd, Craven Arms, UK) [16].

PCR bands of 55 different hospital samples were cluster-analysed with Bionumerics software (Applied Maths, Gent, Belgium) to determine the similarity of RISA-PCR profiles between hospitals and wards. Similarity was determined using Pearson coefficient [17].

Microbial species determination by DNA analysis (next generation sequencing)

DNA was extracted and quantified as described above. Next generation sequencing (NGS) and quality analysis of FASTQ sequence reads was performed by BaseClear Group, Netherlands. The 16S rRNA gene (V3-V4) was PCR amplified before sequencing. The Illumina MiSeq (PE300) system was used to generate paired-end sequence reads and blc2fastq2 2.18 software was utilised to produce FASTQ sequence files. Reads were filtered and clipped. Raw sequences were analysed with open source software Edge Bioinformatics (v.1.5.1)

\section{Scanning electron microscope (SEM) analysis}

Three randomly selected samples from keyboards, folders, hospital commode and chair seating were analysed with SEM to visualise the presence of dry biofilms. Samples were prepared by overnight incubation in $2.5 \%$ glutaraldehyde solution (Contain ${ }^{\mathrm{TM}}$, Fisher Scientific, Loughborough, UK) followed by immersion in successive concentrations of ethanol for 10 minutes each $(10 \%, 25 \%, 50 \%, 70 \%, 90 \%, 100 \%)$. Prior to SEM scanning, samples were coated with $20 \mathrm{~nm}$ AuPd coating with sputter coater (SC500, Biorad, UK). Secondary electron images were acquired with a beam energy of $5 \mathrm{kV}$ using an in-lens detector on a Sigma HD Field Emission Gun Scanning Electron Microscope (Carl Zeiss Ltd., Cambridge, UK) at 10,000x magnification and 5-7 mm working distance with the help of Earth and Ocean Sciences Department, Cardiff University, UK. 


\section{Statistical analysis}

The strength of linear association between PCR-RISA profiles of dry biofilms recovered from hospital samples was calculated using Pearson coefficient with Bionumerics software (Applied Maths, Gent, Belgium). Higher linear association between two data sets is presented by higher absolute value of Pearson coefficient [17]. The Pearson coefficient values were re-calculated into percentage to better reflect the correlation between PCR-RISA data sets.

\section{RESULTS}

\section{Bacterial presence on hospital sample surfaces}

No planktonic bacteria were recovered from any of the 61 samples investigated after multiple rinsing steps with sterile water. Bacterial growth in a nutrient rich broth was observed in $95 \%$ of samples (58/61) (Table I). The assumption was made that bacterial growth resulted from the presence of sessile bacteria embedded within the dry surfaces, which was confirmed by SEM analysis. Most of the samples (76\%) produced growth within 24 hours (Table I).

DNA analysis (RISA-PCR)

RISA-PCR bands of bacterial cultures recovered from samples were analysed to determine the consistency of microbial composition between wards from the same hospital and between hospitals (Figure 1). Cluster analysis showed that the majority of bacterial cultures share a part of genome, regardless of the sample type or origin. The PCR profiles of hospital samples are convergent in $49 \%$, meaning that the similarity between samples is high. Similarity of bacterial cultures is consistent within samples originating from hospitals $A$ and $B$ with $53 \%$ and $45 \%$ similarity, but lower for hospital C with $38 \%$ similarity.

DNA analysis - next generation sequencing (NGS)

The DNA analysis of the bacterial species recovered from broth cultures following incubation of hospital samples was performed by next generation sequencing. NGS allowed more precise 
and detailed analysis of bacterial cultures' composition than RISA-PCR (Figure 2). Bacterial species found from the hospital samples contained mainly staphylococci and Bacillus spp. The most common bacteria identified were S. aureus, Staphylococcus saprophyticus and Staphylococcus epidermidis, with Bacillus licheniformis and Bacillus subtilis being the most common Bacillus spp. The only Gram-negative DNA isolated was that of Pseudomonas spp. (Figure 2).

An average of 18 different bacterial species were present on each surface analysed from the dry surface samples.

Dominance of particular species was associated with their origin (Figure 3). Samples isolated from hospitals A and B mostly contained S. aureus and S. epidermidis (34.6\% and $24.6 \%$ in hospital $A, 23.8 \%$ and $24.2 \%$ in hospital $B$, respectively). The most common bacteria found from hospital C samples were S. saprophyticus and B. subtilis $(20.6 \%$ and $19.1 \%$, respectively).

Staphylococci generally dominated on hospital A and B surfaces ( $66 \%$ and $53 \%$ of dry biofilm composition, respectively), whereas in hospital C, Bacillus spp. were dominant (68\% of dry biofilm composition).

Scanning electron microscope (SEM) analysis

The previous experiments indicated the presence of multiple sessile bacterial species on the surfaces from dry hospital surfaces. SEM was used to visualise the presence and complexity of dry biofilms formed on these surfaces. Samples varied in their composition and presence of matrix. These dry biofilms formed random clusters of bacterial biofilm on surfaces (Figure 4).

\section{DISCUSSION}

A biofilm is a complex community of microorganisms embedded in self-produced extracellular polymeric matrix, markedly different from their planktonic state equivalent [18]. Most biofilm studies are associated with wet biofilms sessile microorganisms grown in aqueous habitats. 
Little attention has been paid to biofilms grown in dry environments, despite their presence on dry hospital surfaces [19]. There is no standardised method for biofilm detection on surfaces [12]. Nevertheless, an approach was developed to identify the presence of dry biofilm on healthcare surfaces. No viable bacteria were grown following rinsing dry surface samples, suggesting that no planktonic bacteria were present. However, by immersing the sample surfaces in nutrient broth and following incubation, we were able to detect multiple bacterial species from the surfaces, and scattered random microbial biofilm were observed by SEM. Indeed, almost all samples (95\%) harboured dry biofilms. Similar results were obtained by Hu et al. in 2015 , who confirmed the presence of biofilm on $41 / 44(93 \%)$ hospital surface samples [14]. It is conceivable that the rinsing step including vortexing may have contributed to dislodging loosely attached bacteria/biofilm [20]. Our results showed, however, that the majority of surfaces bear dry biofilms that were not removed or loosen by the multiple rinsing steps.

Our study shows staphylococci and Bacillus spp. to be the main bacterial genera recovered from the dry biofilms. It was surprising to see some variability between hospitals whereby in one study hospital Bacillus spp. were the dominant bacteria. These differences may be explained by hospital size, antimicrobial consumption, ventilation and patient infections, since patients shed pathogens onto surfaces around them, cleaning and disinfection regimens, which will impact on soiling, and possibly differences in the item sampled [21]. Here, the three hospitals varied in size: hospitals $A$ and $C$ are 1500 bed teaching hospital in wales and in London, whereas hospital B is a Scottish district general hospital with 550 beds. Detergents are used for routine cleaning in all three hospitals, although in hospital $A$, there is proportionately greater use of chlorine-based disinfectants. All three hospitals utilised a terminal cleaning regimen with bleach-type agents for areas exposed to known pathogens such as carbapenemase-producing Enterobacteriaceae (CPE), norovirus, C. difficile, MRSA, VRE, etc. We cannot comment on the type of patients or their infections as that information was not collected during this study. Despite these differences, it was remarkable that dry 
biofilms on the sampled surfaces were widespread and that there was a good similarity of the dry biofilm microbial composition from two hospitals. The local environment (urban vs. rural) could also play some parts. For example, external building work has been associated with increased number of Bacillus spores in healthcare facilities [22,23]. Here, no external building work was reported near or within hospital $C$ at the time of sampling, which would have explained the high level of Bacillus spp. observed.

Among staphylococcal isolates identified, S. aureus, S. saprophyticus and S. epidermidis were the dominant species. MRSA was cultured from a high proportion of samples. The clinical risk associated with this finding is yet to be determined. Among Bacillus spp., the prevalent species were $B$. licheniformis and $B$. subtilis. These results differ from the study by Hu et al. in which no Bacillus spp. were reported, although the authors analysed only samples from the critical care environment [14]. Nevertheless, it is clear that composition of the isolated biofilms is a mixture of environmental, skin and gut microflora, including pathogens. The complexity of composition has been reported for biofilm from different surfaces, although overall composition depends on the object sampled [14]. Our study showed some variability in the detailed composition of the biofilm for the same object between different hospitals. However, variability in microbial composition decreased between different objects from the same hospital. It is likely that each hospital has its own unique environmentome, which is reflected in the composition of biofilm on items and surfaces.

We and others have not addressed the formation of complex dry biofilm on environmental surfaces in healthcare settings $[13,14]$. Bacterial stress such as desiccation and exposure to chemicals can enhance the production of extracellular polysaccharides [24-26], which can protect biofilms from adverse chemical and physical effects $[27,28]$. More of a concern is the report of the ineffectiveness of disinfection, notably chlorine-based agents, against dry biofilms, and how this impacts on infection control [14,29]. The high prevalence of S. aureus, and MRSA in particular, from dry biofilm from the surfaces sampled adds to that concern, 
since MRSA is known to be transmitted through environmental contamination [30]. The presence and transmission of pathogens in dry biofilms from healthcare surfaces warrants further examination [31,32]. The risk associated with bacterial pathogens recovered in dry biofilms with HCAls is yet to be determined. Some studies link the survival rates of biofilmforming strains with persistent nosocomial infections and outbreaks [33,34]. The role of Bacillus spp. in protecting bacterial pathogens in biofilm from disinfection also needs to be addressed [34-38].

\section{Conclusion}

Our study provides more evidence that complex dry biofilms containing bacterial pathogens are virtually universal on hospital surfaces, despite regular cleaning and disinfection. These dry biofilms were shown to occur in clusters on different materials and were predominantly formed by Gram-positive bacteria although occasional Acinetobacter spp. were identified. Unlike other studies, we identified a large proportion of Bacillus spp. The role of Bacillus spp. in protecting mixed biofilm community from environmental conditions and disinfection should be further investigated [38]. Although these dry biofilms are clearly harboring pathogens, their role in transmission needs to be established. This is particularly important in view of the failing of disinfection to control these biofilms and the general absence of testing and biocidal products claiming efficacy against dry biofilms.

\section{References}

[1] Public Health England. English Surveillance Programme for Antimicrobial Utilisation and Resistance, https://assets.publishing.service.gov.uk/government/uploads/system/uploads/attachmen t_data/file/656611/ESPAUR_report_2017.pdf; 2017 [accessed 23 April 2018]

[2] Naylor NR, Atun R, Zhu N, Kulasabanathan K, Sachin S, Chatterjee, et al. Estimating the burden of antimicrobial resistance: a systematic literature review. Antimicrob Resist Infect Control 2018;7:58. 
[3] National Audit Office. Reducing healthcare associated infections in hospitals in England, https://www.nao.org.uk/report/reducing-healthcare-associated-infections-in-hospitals-inengland/; 2009 [accessed 11 April 2018].

[4] National Audit Office. The management and control of hospital acquired infection in acute NHS trusts in England, https://www.nao.org.uk/report/the-management-and-control-ofhospital-acquired-infection-in-acute-nhs-trusts-in-england/; 2000 [accessed 11 April 2018].

[5] Dancer SJ. Do's and Don'ts for hospital cleaning. Curr Opin Infect Dis 2016;29:415-23.

[6] Siani H, Wesgate R, Maillard J-Y. Impact of antimicrobial wipe compared with hypochlorite solution on environmental surface contamination in a healthcare setting: a double crossover study. Am J Infect Control, in press.

[7] Dancer SJ, White LF, Lamb J, Girvan EK, Robertson C. Measuring the effect of enhanced cleaning in a UK hospital: a prospective cross-over study. BMC Med $2009 ; 7: 28$

[8] Care Quality Commission. Care Quality Commission inpatient satisfaction survey, http://www.nhsconfed.org/resources/key-statistics-on-the-nhs; 2016 [accessed 10 January 2018].

[9] Dancer S. The role of environmental cleaning in the control of hospital-acquired infection. J Hosp Infect 2009;73:378-85.

[10] Mitchell BG, Dancer SJ, Anderson M, Dehn E. Risk of organism acquisition and prior room occupancy: A systematic review and meta-analysis. J Hosp Infect 2015;91:211-7.

[11] Kramer A, Schwebke I, Kampf G. How long do nosocomial pathogens persist on inanimate surfaces? a systematic review. BMC Infect Dis 2006;6:130.

[12] Percival S, Williams D, Cooper T, Randle J. Biofilms in infection prevention and control: A healthcare handbook. 1st ed. Elsevier; 2014.

[13] Vickery K, Deva A, Jacombs A, Allan J, Valente P, Gosbell I. Presence of biofilm containing viable multiresistant organisms despite terminal cleaning on clinical surfaces in an intensive care unit. J. Hosp Infect 2012;80:52-5. 
[14] Hu H, Johani K, Gosbell I, Jacombs A, Almatroudi A, Whiteley G et al. Intensive care unit environmental surfaces are contaminated by multidrug-resistant bacteria in biofilms: combined results of conventional culture, pyrosequencing, scanning electron microscopy, and confocal laser microscopy. J Hosp Infect 2015;91:35-44.

[15] Jones SE, Shade AL, McMahon KD, Kent AD. Comparison of primer sets for use in automated ribosomal intergenic spacer analysis of aquatic bacterial communities: an ecological perspective. Appl Environ Microbiol 2007;73:659-62.

[16] Panaro N, Yuen P, Sakazume T, Fortina P, Kricka L, Wilding, P. Evaluation of DNA fragment sizing and quantification by the Agilent 2100 Bioanalyzer. Clin Chem 2000; $46: 1851-3$

[17] Pearson K. Note on regression and inheritance in the case of two parents. Proceed Royal Soc London 1985;58:240-2.

[18] Costerton JW, Lewandowski Z, Caldwell DE, Korber DR, Lappin-Scott HM. Microbial Biofilms. Annu Rev Microbiol 1995;49:711-45.

[19] Almatroudi A, Hu H, Deva A, Gosbell IB, Jacombs A, Jensen SO et al. A new drysurface biofilm model: An essential tool for efficacy testing of hospital surface decontamination procedures. J Microbiol Methods 2015;117:171-6.

[20] Kobayashi H, Oethinger M, Tuohy MJ, Procop GW, Bauer TW. Improved Detection of Biofilm-formative Bacteria by Vortexing and Sonication: A Pilot Study. Clin Orthop Relat Res. 2009;467: 360-4.

[21] Hayden MK, Blom DW, Lyle EA, Moore CG, Weinstein RA. Risk of hand or glove contamination after contact with patients colonized with vancomycin-resistant enterococcus or the colonized patients' environment. Infect Control Hosp Epidemiol 2008;29:149-54.

[22] Balm MND, Jureen R, Teo C, Yeoh AEJ, Lin RTP, Dancer SJ et al. Hot and steamy: outbreak of Bacillus cereus in Singapore associated with construction work and laundry practices. J Hosp Infect 2012;81:224-30. 
[23] Loeb M, Wilcox L, Thornley D, Gun-Munro J, Richardson H. Bacillus species pseudobacteremia following hospital construction. Can J Infect Control 1995;10:37-40.

[24] Machado I, Lopes SP, Sousa AM, Pereira MO. Adaptive response of single and binary Pseudomonas aeruginosa and Escherichia coli biofilms to benzalkonium chloride. J Basic Microbiol 2002;52:43-52.

[25] Chang WS, Halverson LJ. Reduced water availability influences the dynamics, development, and ultrastructural properties of Pseudomonas putida biofilms. J Bacteriol 2003;185:6199-204.

[26] Türetgen I, Ilhan-Sungur E, Cotuk A. Effects of short-time drying on biofilm-associated bacteria. Ann Microbiol 2007;57:277-80.

[27] Maillard J-Y, Denyer SP. Emerging bacterial resistance following biocide exposure: should we be concerned? Chemi Ogg 2009;27:26-8.

[28] Otter JA, Vickery K, Walker JT, deLancey Pulcini E, Stoodley P, Goldenberg SD et al. Surface-attached cells, biofilms and biocide susceptibility: implications for hospital cleaning and disinfection. J Hosp Infect 2015;89:16-27.

[29] Almatroudi A, Gosbell IB, Hu H, Jensen SO, Espedido BA, Tahir S et al. Staphylococcus aureus dry-surface biofilms are not killed by sodium hypochlorite: implications for infection control. J Hosp Infect 2016;93:263-70.

[30] Dancer SJ. Importance of the environment in MRSA acquisition: the case for hospital cleaning. Lancet Infect Dis 2008;8:101-13.

[31] Kovacs-Litman A, Wong K, Shojania K, Callery S, Vearncombe M, Leis J. Do physicians clean their hands? Insights from a covert observational study. J Hosp Med 2016;11:8624.

[32] Cheeseman KE, Denyer SP, Hosein IK, Williams GJ, Maillard J-Y. Evaluation of the bactericidal efficacy of three different alcohol hand rubs against 57 clinical isolates of Staphylococcus aureus. J Hosp Infect 2009;72:319-25.

[33] Espinal P, Marti S, Vila J. Effect of biofilm formation on the survival of Acinetobacter baumannii on dry surfaces. J Hosp Infect 2012; 80:1:56-60. 
[34] Yezli S, Otter JA. Does the discovery of biofilms on dry hospital environmental surfaces change the way we think about hospital disinfection? J Hosp Infect 2012;81:292-4.

[35] Haydushka I, Markova N, Kirina V, Atanassova M. Recurrent sepsis due to Bacillus licheniformis. J Glob Infect Dis 2012;4:82-3.

[36] Blue S, Singh S, Saubolle M. Bacillus licheniformis bacteremia: five cases associated with indwelling central venous catheters. Clin Infect Dis 1995;20:629-33.

[37] de Boer A, Diderichsen B. On the safety of Bacillus subtilis and B. amyloliquefaciens: a review. Appl Microbiol Biotechnol 1991;36:1-4.

[38] Bridier A, Le Coq D, del Pilar Sanchez-Vizuete M, Aymerich S, Meylheuc T, Maillard J-Y et al. Biofilms of a Bacillus subtilis endoscope WD isolate that protect Staphylococcus aureus from peracetic acid. PLoS ONE 2012;7:e44506

\section{Acknowledgements}

A very special gratitude to Drs $L$ Rushton, $R$ Weiser and Prof. E Mahenthiralingam from the School of Biosciences, Cardiff University for their help in RISA-PCR analysis. We would also like to thank Dr Duncan Muir at School of Earth and Ocean Sciences, Cardiff University for his valuable help in acquiring SEM images of hospital samples.

\section{Funding}

This project was supported from a grant (SRG/2016_07/001) from by the Healthcare Infection Society. J A Otter would like to acknowledge support from the National Institute for Health Research Health Protection Research Unit (NIHR HPRU) in Healthcare-Associated Infections and Antimicrobial Resistance at Imperial College London in partnership with Public Health England (PHE), and the Imperial College Healthcare Trust NIHR Biomedical Research Centre (BRC).

\section{Conflict of interest}


K Ledwoch is partly funded by GAMA Healthcare Ltd. J A Otter is a consultant to GAMA Healthcare Ltd, and has been a consultant to Pfizer in the last three years. 
Figure 1 Cluster analysis of PCR-RISA bands of cultures recovered from hospital samples (keyboards and folders). The scale gives the similarity between a pair of two samples (in a range of $0-100 \%$, where $0 \%$ indicates no correlation, and $100 \%$ indicates complete convergence in RISA-PCR profiles). Red dots indicate pairs of the same samples, which are not taken into account in analysis.

Figure 2 Percentage of samples containing given species following DNA analysis - all samples pooled.

Figure 3 Difference in "dry" biofilm composition between hospitals. Anoxybacillus flavithermus: - Bacillus amyloliquefaciens: $\mathbf{n}$, Bacillus anthracis: $\mathbf{\square}$, Bacillus cereus: Bacillus licheniformis: $\square$, Bacillus megaterium: $\square$, Bacillus pumilus: $\square$, Bacillus sp.: $\square$, Bacillus subtilis: $\square$, Bacillus thuringiensis: $\square$, Staphylococcus aureus: $\square$, Staphylococcus epidermidis: ఐ, Staphylococcus lugdenensis: ఐ, Staphylococcus pasteuri: घ, Staphylococcus saprophyticus: $\mathbf{n}$, Staphylococcus warneri: $\square$, OTHER:

Figure 4. Examples of "dry" biofilms recovered from surfaces; magnification $X 10,000$. A) and B) Patient folders, C) patient chair, D) keyboard key. Images of biofilms were coloured in purple to help visualisation and contrast using GNU Image manipulation program (GIMP 2.8) software. Images were not otherwise altered. 
Fig. 1

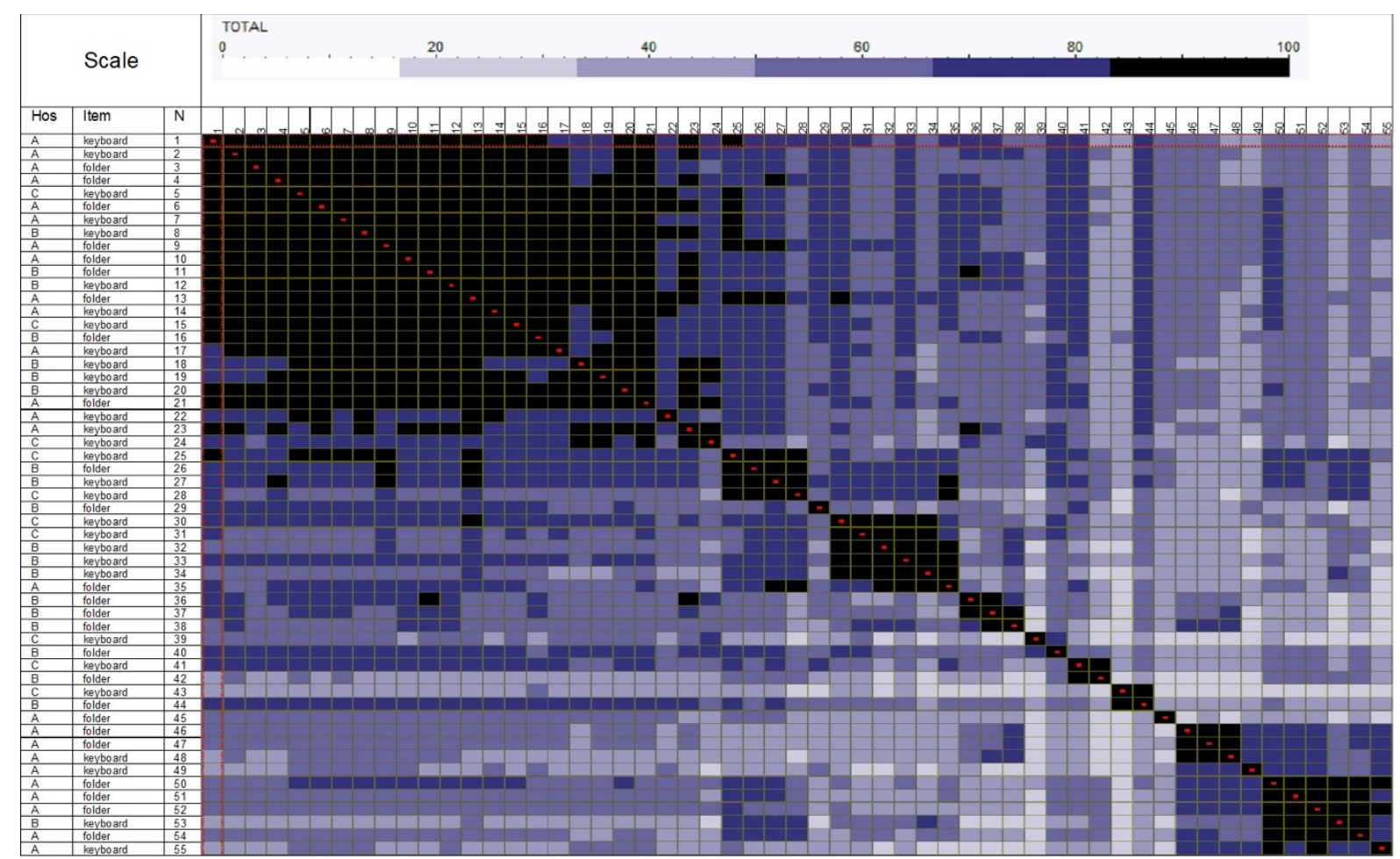


Fig. 2

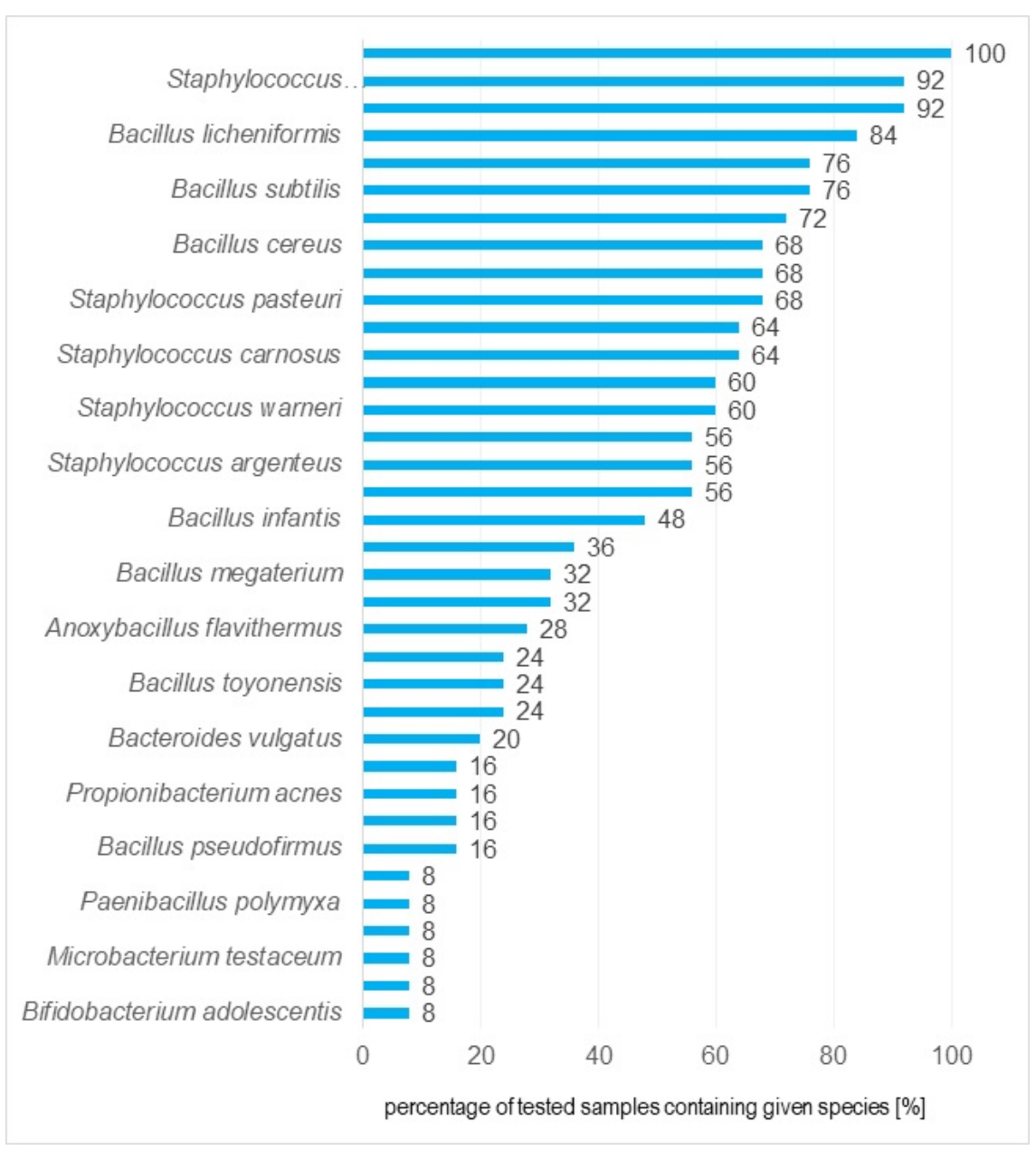


Fig. 3

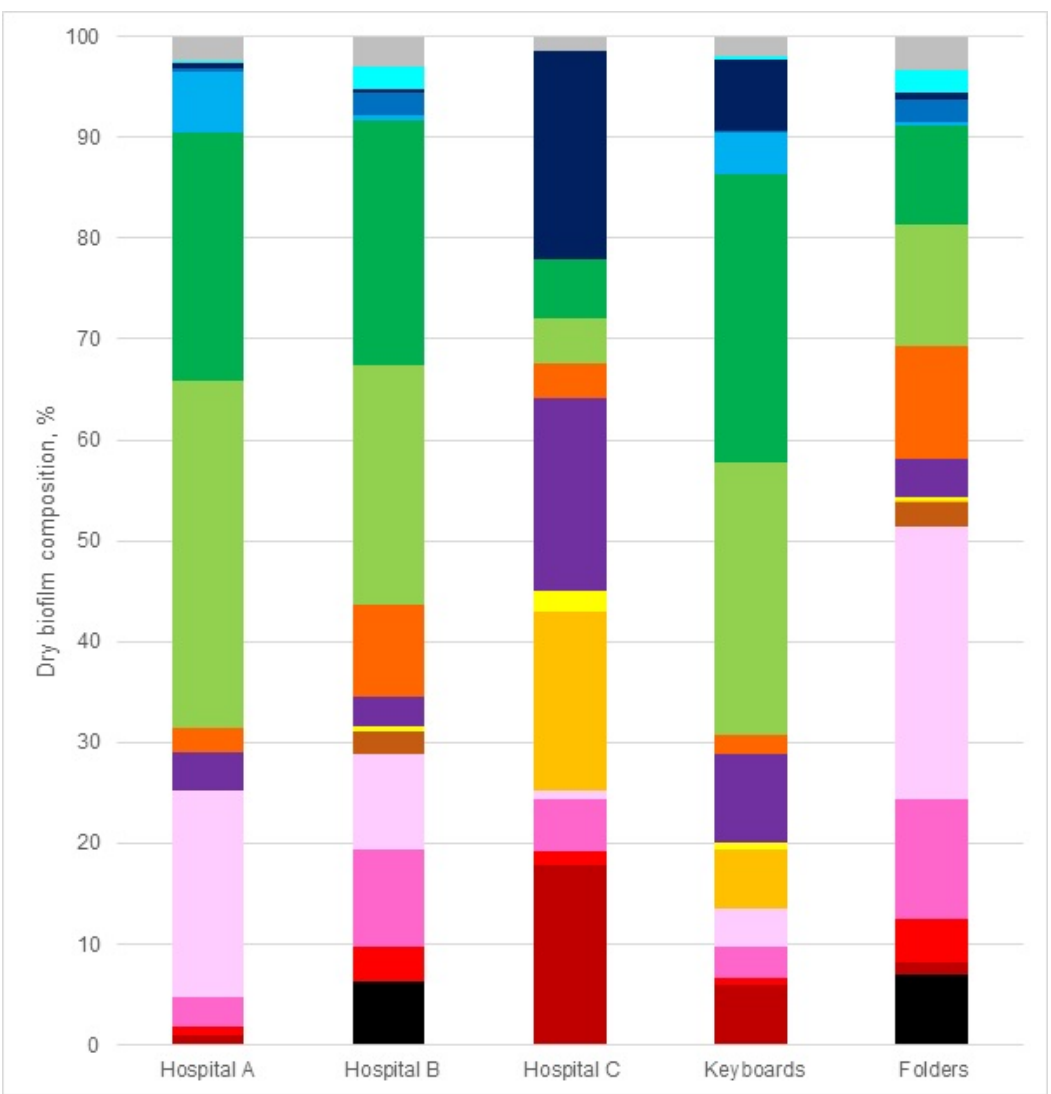


Fig. 4

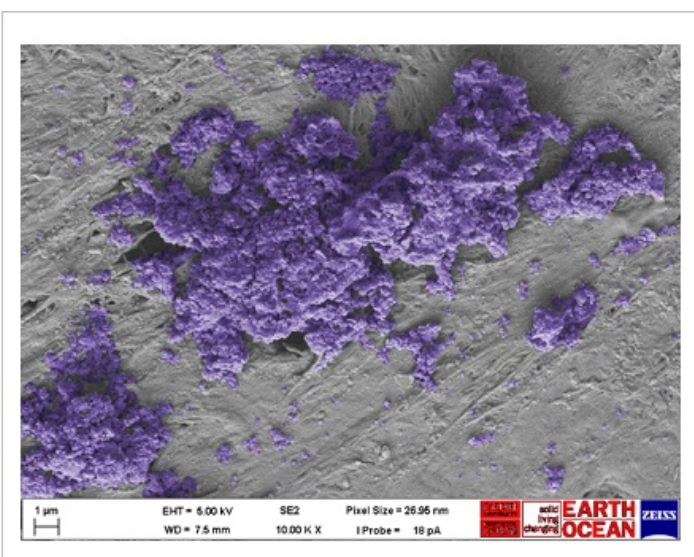

A)

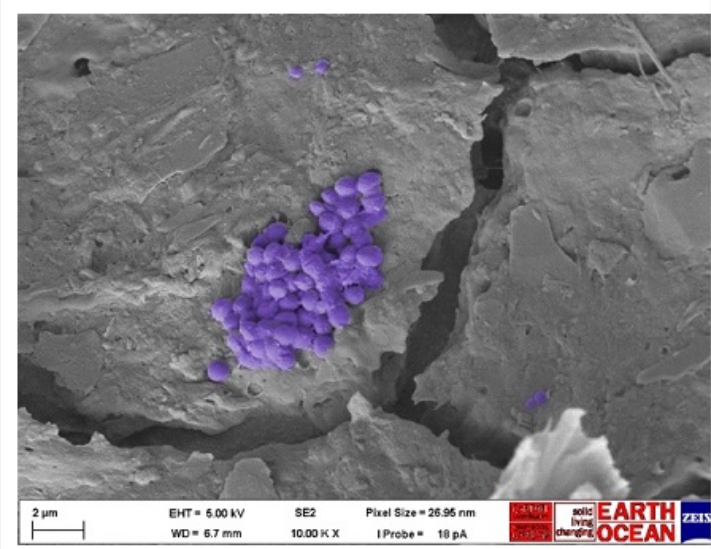

C)

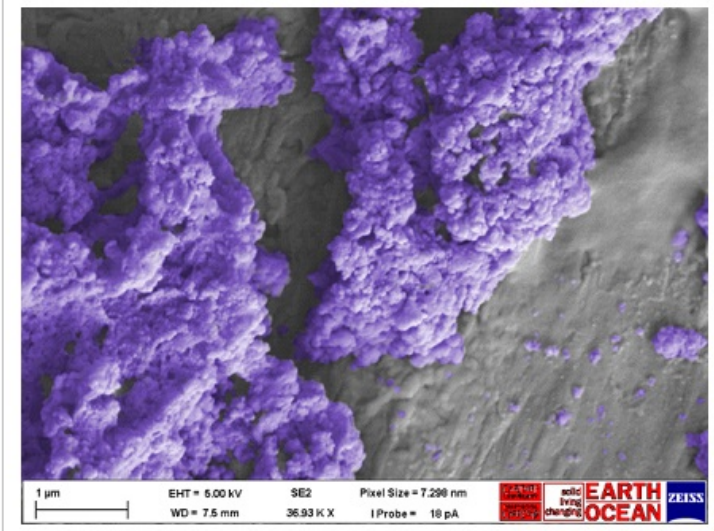

B)

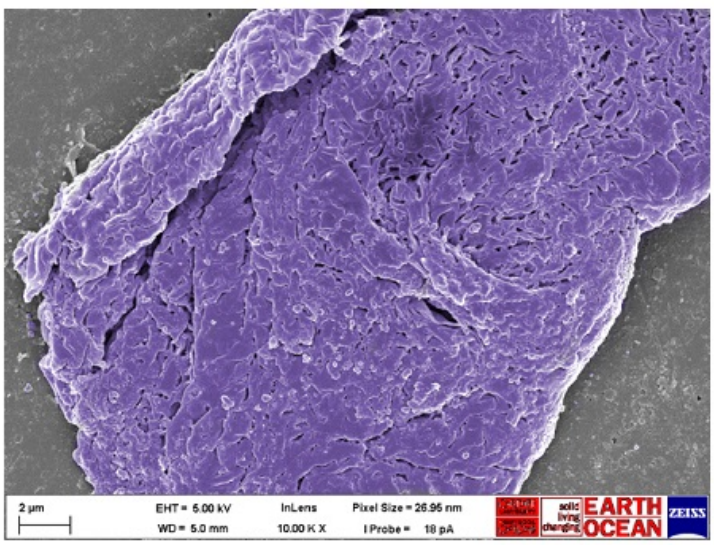

D) 
Table I Samples and time for bacterial regrowth in TSB following rinsing

\begin{tabular}{|c|c|c|c|c|c|c|c|c|c|c|c|}
\hline \multicolumn{4}{|c|}{ Hospital A } & \multicolumn{4}{|c|}{ Hospital B } & \multicolumn{4}{|c|}{ Hospital C } \\
\hline $\begin{array}{l}\text { Sample } \\
\text { number }\end{array}$ & Department/Ward & $\begin{array}{l}\text { Sample } \\
\text { type }\end{array}$ & $\begin{array}{l}\text { Regrowth } \\
\text { (days) }^{1}\end{array}$ & $\begin{array}{l}\text { Sample } \\
\text { number }\end{array}$ & Department/ward & $\begin{array}{l}\text { Sample } \\
\text { type }\end{array}$ & $\begin{array}{l}\text { Regrowth } \\
\text { (days) }^{1}\end{array}$ & $\begin{array}{l}\text { Sample } \\
\text { number }\end{array}$ & $\begin{array}{c}\text { Department/ } \\
\text { Ward }\end{array}$ & $\begin{array}{l}\text { Sample } \\
\text { type }\end{array}$ & $\begin{array}{l}\text { Regrowth } \\
\text { (days) }^{1}\end{array}$ \\
\hline 1 & \multirow{5}{*}{ Gastroenterology } & folder & 1 & 32 & \multirow{7}{*}{ Microbiology } & $\begin{array}{l}\text { patient } \\
\text { folder }\end{array}$ & 1 & 52 & $\begin{array}{c}\text { Acute admission } \\
\text { unit }\end{array}$ & keyboard & $\begin{array}{c}\text { no } \\
\text { regrowth } 2\end{array}$ \\
\hline 2 & & $\begin{array}{l}\text { wooden } \\
\text { tray (food } \\
\text { trolley) }\end{array}$ & $\begin{array}{c}\text { no } \\
\text { regrowth }{ }^{2}\end{array}$ & 33 & & $\begin{array}{l}\text { patient } \\
\text { folder }\end{array}$ & 1 & 53 & $\begin{array}{l}\text { Kidney and } \\
\text { transplant }\end{array}$ & keyboard & 4 \\
\hline 3 & & $\begin{array}{l}\text { hospital } \\
\text { commode }\end{array}$ & 1 & 34 & & $\begin{array}{l}\text { patient } \\
\text { folder }\end{array}$ & 1 & 54 & $\begin{array}{c}\text { Cancer services } \\
\text { and } \\
\text { haematological } \\
\text { malignancies }\end{array}$ & keyboard & 6 \\
\hline 4 & & $\begin{array}{l}\text { leather } \\
\text { chair } \\
\text { seating } \\
\end{array}$ & 1 & 35 & & $\begin{array}{l}\text { patient } \\
\text { folder }\end{array}$ & 1 & 55 & \multirow{2}{*}{$\begin{array}{l}\text { Kidney and } \\
\text { transplant }\end{array}$} & keyboard & 1 \\
\hline 5 & & $\begin{array}{c}\text { fabric chair } \\
\text { back } \\
\text { support }\end{array}$ & 1 & 36 & & $\begin{array}{l}\text { patient } \\
\text { folder }\end{array}$ & 4 & 56 & & keyboard & 1 \\
\hline 6 & \multirow{6}{*}{$\begin{array}{c}\text { Trauma \& } \\
\text { Orthopaedics }\end{array}$} & $\begin{array}{c}\text { patient } \\
\text { folder }\end{array}$ & 6 & 37 & & $\begin{array}{l}\text { patient } \\
\text { folder }\end{array}$ & 5 & 57 & \multirow{2}{*}{ Cardiology } & keyboard & 1 \\
\hline 7 & & $\begin{array}{l}\text { patient } \\
\text { folder }\end{array}$ & 1 & 38 & & $\begin{array}{l}\text { patient } \\
\text { folder }\end{array}$ & 1 & 58 & & keyboard & 7 \\
\hline 8 & & $\begin{array}{l}\text { patient } \\
\text { folder }\end{array}$ & 1 & 39 & \multirow{2}{*}{ Biochemistry } & $\begin{array}{l}\text { patient } \\
\text { folder }\end{array}$ & 1 & 59 & Acute medicine & keyboard & 1 \\
\hline 9 & & $\begin{array}{l}\text { patient } \\
\text { folder }\end{array}$ & 1 & 40 & & $\begin{array}{l}\text { patient } \\
\text { folder }\end{array}$ & 1 & 60 & \multirow{2}{*}{ Haematology } & keyboard & 1 \\
\hline 10 & & $\begin{array}{l}\text { patient } \\
\text { folder }\end{array}$ & 1 & 41 & Pharmacy & $\begin{array}{l}\text { patient } \\
\text { folder }\end{array}$ & 1 & 61 & & keyboard & $\begin{array}{c}\text { no } \\
\text { regrowth }^{2} \\
\end{array}$ \\
\hline 11 & & $\begin{array}{l}\text { patient } \\
\text { folder }\end{array}$ & 2 & 42 & General medicine & $\begin{array}{c}\text { keyboa } \\
\text { rd }\end{array}$ & 1 & & & & \\
\hline
\end{tabular}




\begin{tabular}{|c|c|c|c|c|c|c|}
\hline 12 & & $\begin{array}{l}\text { patient } \\
\text { folder }\end{array}$ & 1 & 43 & $\begin{array}{c}\text { keyboa } \\
\text { rd }\end{array}$ & 1 \\
\hline 13 & & $\begin{array}{l}\text { patient } \\
\text { folder }\end{array}$ & 1 & 44 & $\begin{array}{l}\text { keyboa } \\
\text { rd }\end{array}$ & 1 \\
\hline 14 & & $\begin{array}{l}\text { patient } \\
\text { folder }\end{array}$ & 1 & 45 & $\begin{array}{c}\text { keyboa } \\
\text { rd }\end{array}$ & 1 \\
\hline 15 & & $\begin{array}{l}\text { patient } \\
\text { folder }\end{array}$ & 1 & 46 & $\begin{array}{c}\text { keyboa } \\
\text { rd }\end{array}$ & 1 \\
\hline 16 & $\begin{array}{l}\text { Adult Intensive } \\
\text { Care }\end{array}$ & keyboard & 1 & 47 & $\begin{array}{l}\text { keyboa } \\
\text { rd }\end{array}$ & 1 \\
\hline 17 & & keyboard & 1 & 48 & $\begin{array}{l}\text { keyboa } \\
\text { rd }\end{array}$ & 1 \\
\hline 18 & & keyboard & 1 & 49 & $\begin{array}{l}\text { keyboa } \\
\text { rd }\end{array}$ & 1 \\
\hline 19 & $\begin{array}{l}\text { Acute Short Stay } \\
\text { Medicine }\end{array}$ & keyboard & 2 & 50 & $\begin{array}{l}\text { keyboa } \\
\text { rd }\end{array}$ & 1 \\
\hline 20 & & keyboard & 1 & 51 & $\begin{array}{l}\text { keyboa } \\
\text { rd }\end{array}$ & 1 \\
\hline 21 & & keyboard & 2 & & & \\
\hline 22 & & keyboard & 4 & & & \\
\hline 23 & Gastroenterology & keyboard & 1 & & & \\
\hline 24 & & keyboard & 4 & & & \\
\hline 25 & & keyboard & 6 & & & \\
\hline 26 & Nephrology & keyboard & 9 & & & \\
\hline 27 & & keyboard & 1 & & & \\
\hline 28 & & keyboard & 7 & & & \\
\hline 29 & & keyboard & 1 & & & \\
\hline 30 & $\begin{array}{l}\text { Trauma \& } \\
\text { Orthopaedics }\end{array}$ & $\begin{array}{c}\text { sanitising } \\
\text { bottle }\end{array}$ & 1 & & & \\
\hline 31 & & $\begin{array}{l}\text { sanitising } \\
\text { bottle }\end{array}$ & 1 & & & \\
\hline
\end{tabular}

${ }^{1}$ Time for turbidity to developed following incubation in TSB. 
${ }^{2}$ No regrowth following $>14$ days incubation 